\title{
Purification of a lectin from Cratylia mollis crude extract seed by a single step PEG/phosphate aqueous two-phase system
}

\author{
Cynthia Oliveira Nascimento ${ }^{a}$, Romero Marcos Pedrosa Brandão Costa ${ }^{b}$, Paulo Antônio Soares ${ }^{c}$, Polyanna Nunes \\ Herculano ${ }^{a}$, Tatiana Souza Porto ${ }^{d}$ (D) Thiago Pajeú Nascimento ${ }^{a}$, Carolina de Albuquerque Lima ${ }^{e}$, \\ Raquel Pedrosa Bezerra ${ }^{a}$, José Antônio Teixeira ${ }^{f}$, Luana Cassandra Breitenbach Barroso Coelho ${ }^{c}$, Maria Tereza \\ dos Santos Correia ${ }^{c}$ (D), Maria das Graças Carneiro-da-Cunhac, and Ana Lúcia Figueiredo Porto ${ }^{a}$ (iD
}

\begin{abstract}
${ }^{a}$ Department of Morphology and Animal Physiology, Federal Rural University of Pernambuco, Recife, Brazil; ${ }^{b}$ Institute of Biological Sciences, University of Pernambuco, Recife, Pernambuco, Brazil; 'Department of Biochemistry and Biophysics, Federal University of Pernambuco, Recife, Brazil; ${ }^{d}$ Academic Unit of Garanhuns (UAG), Federal Rural University of Pernambuco (UFRPE), Garanhuns, Brazil; ${ }^{e}$ Faculty of Science, Education and Technology of Garanhuns, University of Pernambuco - UPE, Garanhuns, Brazil; Institute for Biotechnology and Bioengineering, Centre of Biological Engineering, University of Minho, Braga, Portugal
\end{abstract}

\begin{abstract}
The partitioning and purification of lectins from the crude extract of Cratylia mollis seeds (Cramoll $1,4)$ was investigated in aqueous two-phase systems (ATPS). A factorial design model $\left(2^{4}\right)$ was used to evaluate the influence of polyethylene glycol (PEG) molar mass $(1500-8000 \mathrm{~g} / \mathrm{mol})$, PEG concentration $(12.5-17.5 \% \mathrm{w} / \mathrm{w})$, phosphate $(10-15 \% \mathrm{w} / \mathrm{w})$ concentration, and $\mathrm{pH}(6-8)$ on the differential partitioning, purification factor, and yield of the lectin. Polymer and salt concentration were the most important variables affecting partition of lectin and used to find optimum purification factor by experimental Box-Behnken design together with the response surface methodology (RSM). ATPS showed best conditions composed by 13.9\% PEG1500, 15.3\% phosphate buffer at pH 6 , which ensured purification factor of 4.70 . Sodium dodecyl sulfate-polyacrylamide gel electrophoresis showed a single band of protein with $26.1 \mathrm{kDa}$. Furthermore, results demonstrated a thermostable lectin presenting activity until $60^{\circ} \mathrm{C}$ and lost hemagglutinating activity at $80^{\circ} \mathrm{C}$. According to the obtained data it can be inferred that the ATPS optimization using RSM approach can be applied for recovery and purification of lectins.
\end{abstract}

\section{KEYWORDS}

ATPS; Cratylia mollis seeds; lectins; partitioning; purification factor

\section{Introduction}

Various proteins have the capacity to recognize specifically and reversely different substances in organisms. Wellknown examples are proteins able to bind to substrates or inhibitors that can specifically recognize an epitope at the surface of a cell membrane. ${ }^{[1]}$ Lectins are carbohydratebinding proteins with substantial structural diversity in the biology world; they bind selectively and non-covalently to carbohydrate residues and are involved in several biological processes and activities like antibacterial and antifungal assays. ${ }^{[2]}$

Proteins with ability to recognize other molecules are widely distributed in nature and can be found in plants, animals, algae, humans, microorganisms, and virus. Although they have been isolated from organisms from all kingdoms of life, lectins produced by plants and animals remain the best characterized. Cratylia mollis (camaratu bean Fabaceae family) is native leguminous forage from the Semiarid Region of the Northeast of Brazil. C. mollis lectin (Cramoll) lectin has several isolectins and isoforms with specificity to different carbohydrates-Cramoll 1, Cramoll 2, and Cramoll 4 are non-glycosylated proteins, glucose/ mannose specific; and Cramoll 3, a glycoprotein, is galactose specific. $^{[3,4]}$ A mannose/glucose specific lectin from the seeds of this plant, Cramoll 1, 4 (preparation containing isolectins 1 and 4; pCramoll), with a potent hemagglutinating activity was obtained by affinity chromatography by Correia and Coelho. ${ }^{[4]}$ Initially, firstly reports about the biological applications of Cramoll 1,4 were biomarkers of cancer, ${ }^{[5]}$ mitogenic, ${ }^{[6]}$ and antitumor activities. ${ }^{[7]}$ However, nowadays, immobilized C. mollis isolectins allowed the isolation of trypsin inhibitor from Echinodorus paniculatus seeds ${ }^{[8]}$ and could be as a potential matrix to isolate plasma glycoproteins, including lecithin-cholesterol acyltransferase ${ }^{[9]}$ and could be acted on immunomodulatory response. ${ }^{[10]} \mathrm{New}$ researches in biomedical applications include the histochemical evaluation of human prostatic tissues, ${ }^{[11]}$ as anti-parasite agent, ${ }^{[12]}$ mitogenic response, and cytokine in splenocytes of inoculated mice ${ }^{[13]}$ and the use as an affinity matrix to purify a soybean (Glycine max). ${ }^{[14]}$

pCramoll and rCramoll have been reported to induce immunomodulatory response on peritoneal exudate cells (PECs) infected and non-infected with Staphylococcus aureus, ${ }^{[15]}$ pCramoll nanoelectrode for differential diagnostic of 
prostate cancer and benign prostatic hyperplasia based on label-free detection. ${ }^{[5]}$ Encapsulation into stealth liposomes enhances the antitumor action of recombinant $C$. mollis lectin expressed in Escherichia coli. ${ }^{[15]}$ Besides, plants lectins have other several biomedical and pharmacological applications ${ }^{[16]}$ and recently Oliveira et al. ${ }^{[17]}$ in their study published insecticidal activity against Aedes aegypti.

Purification processes of lectins have been used by biomedical industries to obtain quantities of proteins be able to use in therapeutics activities. Partitioning in aqueous twophase system (ATPS) has been shown to be a powerful tool for separating and purifying mixtures of proteins ${ }^{[18-20]}$ and is considered as a very attractive alternative to more conventional technologies such as chromatography. ${ }^{[21]}$ ATPSs techniques are formed when two mutually incompatible hydrophilic solutes are dissolved in water above a certain critical concentration ${ }^{[22-25]}$ and have successfully applied in the purification of different biological materials such as cells, virus, organelles, nucleic acids, proteins, and enzymes. ${ }^{[20-26]}$

Since some of techniques have been used to purify lectins, to facilitate the development of extraction process in ATPSs several basic steps should be followed. At first the selection of the ATPS, since polymer-polymer or polymersalt systems can be used. This selection is often ruled by economic considerations and the low cost of chemicals used makes polymer-salt systems preferred as first step. ${ }^{[21]}$ Second, a phase diagram is needed to define what system composition will be assayed. Finally, further experimental work must be carried out to know the partitioning behavior of a protein in each ATPS depending on its physical properties such as size,${ }^{[27]}$ net charge, ${ }^{[28]}$ and hydrophobicity. ${ }^{[29]}$ Furthermore, the ATPS characteristics, such as $\mathrm{pH}$, buffer, type, amount of salt, and temperature have effect on proteins behavior. Besides, the partition behavior of protein may be altered with the influence of other proteins and non-proteinaceous substances. ${ }^{[30]}$

ATPS technique has been applied for partition and recovery of protease, ${ }^{[31]}$ antibodies, ${ }^{[32]} \alpha$-amylase, ${ }^{[25,33]}$ glyco-macropeptide, ${ }^{[34]}$ lipase, ${ }^{[35,36]}$ plasmid $\mathrm{DNA},{ }^{[37]}$ lysozyme, ${ }^{[38]}$ ascorbate oxidase, ${ }^{[39]} \quad \beta$-galactosidase, ${ }^{[40]}$ fibrinolytic enzyme, ${ }^{[20,40]}$ and polygalacturonate ${ }^{[41]}$ but also, lectins. ${ }^{[42-46]}$

Statistical design of experiments has been widely used for optimization of extraction/purification of biomolecules in ATPS, ${ }^{[25,47]}$ as it allows the estimating of the significant effects of the extraction variables on the selected responses, as well as their possible interactions. ${ }^{[48]}$

Hence, the aim of this work was to determine the optimal conditions for the recovery/purification of lectins from the crude extract of C. mollis seeds, by ATPS polyethylene glycol (PEG) /phosphate using factorial and central composite design, respectively.

\section{Materials and methods}

\section{Crude extract}

Cratylia mollis seeds were collected in Federal University of Pernambuco campus and the seeds were processed by grinding using a domestic blender, and the fine particles were separated by sieving less than $1.6 \mathrm{~mm}$. The extract was obtained by immersion of pulverizing dried seeds $(10 \%$ (w/v) in $150 \mathrm{mM}$ sodium chloride) followed by agitation overnight at $4{ }^{\circ} \mathrm{C}$. Afterwards, the extract was filtered through gauze and the filtrate centrifuged at $4000 \times g$ for $15 \mathrm{~min}$. The supernatant was termed crude extract (CE).

\section{Preparation of aqueous two-phase systems}

ATPS phase systems were made by mixing appropriate weight solutions of the $40 \%(\mathrm{w} / \mathrm{w})$ of PEG mass molar 1500 , 4000 , and $8000 \mathrm{~g} / \mathrm{mol}$, at room temperature $\left(25 \pm 1{ }^{\circ} \mathrm{C}\right)$. As for the salt solution used was selected the phosphate buffered at $\mathrm{pH}$ 6-8 in concentrations of $50 \%(\mathrm{w} / \mathrm{w})$. The required amounts of this solution were mixed with crude extract representing $20 \%(\mathrm{w} / \mathrm{w})$ of total mass in $15 \mathrm{~mL}$ graduated tubes with conical tips and water was added to complete a $5 \mathrm{~g}$ system. After 1 min-vortex shaking, the two phases were separated by settling for $60 \mathrm{~min}$. The phase volumes were measured separately and utilized for later determination of protein concentration and hemagglutinating activity (HA). To avoid possible interference of PEG and phosphate all samples were analyzed against blanks containing the same phase composition without proteins.

\section{Protein determination}

The protein content was spectrophotometrically determined using bicinchoninic acid according to Smith et al. ${ }^{[49]}$

\section{Determination of the hemagglutinating activity}

The HA was performed in microtiter plates according to Correia and Coelho. ${ }^{[4]}$

\section{Thermal stability of lectin hemagglutinating activity after extraction by aqueous two-phase systems}

To evaluate the thermal stability of lectin, the HA was measured at different temperatures $\left(40-80^{\circ} \mathrm{C}\right)$ for $40 \mathrm{~min}$ according to Correia et al. ${ }^{[4]}$

\section{Experimental design and analysis of the parameters}

The simplified screening of the ATPS extraction parameters for the recovery of lectins from the crude extract of $C$. mollis seeds was carried out with a full two-level factorial design $\left(2^{4}\right)$ to study the effects and interactions of PEG molar mass $\left(M M_{\mathrm{PEG}}\right)$, PEG concentration $\left(C_{\mathrm{PEG}}\right)$, phosphate concentration $\left(C_{\mathrm{P}}\right)$, and $\mathrm{pH}$ on the lectins purification. The responses investigated were the protein $\left(K_{p}\right)$ and HA partition coefficient $\left(K_{H A}\right)$, activity yield $(Y)$, and purification factor $(\mathrm{PF})$.

In the full factorial design, a set of 16 experiments with four replicates at the central point was performed to allow the estimation of pure experimental error. The variables and levels of components under study are presented in Table 1. The values selected for these variables were chosen based on 
Table 1. Factor levels used in the $2^{4}$ factorial designs for the study the influence of independent variables on the lectin purification.

\begin{tabular}{lccc}
\hline & \multicolumn{3}{c}{ Levels } \\
\cline { 2 - 4 } Independent variables (factors) & Lower $(-1)$ & Central $(0)$ & Higher $(+1)$ \\
\hline$M_{\mathrm{PEG}}{ }^{\mathrm{a}}$ & 1500 & 4000 & 8000 \\
$\mathrm{C}_{\mathrm{PEG}}{ }^{\mathrm{a}}$ & 12.5 & 15 & 17.5 \\
$\mathrm{pH}$ & 6.0 & 7.0 & 8.0 \\
$C_{\mathrm{P}}{ }^{\mathrm{C}}$ & 10 & 12.5 & 15 \\
\hline
\end{tabular}

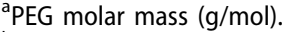

${ }^{\mathrm{b}} \mathrm{PEG}$ concentration (\%).

'Phosphate concentration (\%).

Table 2. Factor and coded levels used in the $2^{2}$ central composite design to lectin purification.

\begin{tabular}{llllll}
\hline & \multicolumn{5}{c}{ Levels } \\
\cline { 2 - 6 } Independent variables & Lower & Central & Higher & Axial & Axial \\
\hline & $(-1)$ & $(0)$ & $(+1)$ & $(-\sqrt{2})$ & $(+\sqrt{ })$ \\
$x_{1}-C_{P E G}{ }^{a}$ & 12.5 & 15 & 17.5 & 11.5 & 18.5 \\
$x_{2}-C_{P}{ }^{b}$ & 12.5 & 15 & 17.5 & 11.5 & 18.5 \\
\hline${ }^{a}$ PEG concentration (\%). & & & & & \\
bPhosphate concentration (\%). & & & &
\end{tabular}

binodal diagrams reported in the literature. ${ }^{[50]}$ The results were statistically analyzed by analysis of variance (ANOVA) at a significance level of $p \leq 0.05$. All statistical and graphical analyses were carried out with the Statistica 8 software (StatSoft Inc., Tulsa, OK).

\section{Optimization of the extraction of lectins from crude extract of $\mathrm{C}$. mollis seeds using response surface methodology}

For response surface methodology (RSM) analysis the model used was a full quadratic Eq. (1)or the diminished form of this equation that can be written as follows:

$$
{ }^{\wedge} y_{i}=b_{0}+\sum b_{i} x_{i}+\sum b_{i i} x_{i}^{2}+\sum b_{i j} x_{i} x_{j}
$$

where $y$ is the dependent variable $\left(K_{\mathrm{P}}, K_{\mathrm{HA}}, \mathrm{PF}\right.$, and $\left.Y\right) ; b_{0}$, $b_{i}, b_{i i}$, and $b_{i j}$ are regression coefficients for intercept, linear, quadratic, and interaction coefficients, respectively; and $x_{i}$ and $x_{j}$ are uncorded independent variables.

For this, a one block central composite design $\left(2^{2}\right)$ comprising 11 experiments, including four factorial points, fourstar (axial) points and three central points was implemented. The limit and center point values for the two independent variables considered-concentration of PEG (\%w/w) $\left(x_{1}\right)$ and phosphate $(\% \mathrm{w} / \mathrm{w})\left(x_{2}\right)$-are presented in Table 2 . Independents variables were based on the result of the initial ATPS screening $\left(2^{4}\right)$. For simplicity, the star points were rounded off with respect to the theoretical values, high (coded value: $+\sqrt{ } 2$ ) and low (coded value: $-\sqrt{ } 2$ ).

Response surface analyses was used to determine the conditions that maximize the selective extraction of the lectin. The graphical representations of these equations can be used to describe the individual and cumulative effect of the test variables on the response. A central composite design (CCD) coupled with a full quadratic polynomial model is a powerful combination that efficiently provides an adequate representation of most continuous responses without expending many resources.

\section{Determination of partition coefficient, yield, and purification factor}

HA partition coefficient $\left(K_{H A}\right)$ was determined as the ratio of hemagglutinating activity in the top phase $\left(H A_{T}\right)$ to that in the bottom phase $\left(H A_{B}\right)$ :

$$
K_{H A}=\frac{H A_{T}}{H A_{B}}
$$

Protein partition coefficient $\left(K_{p}\right)$ was determined as the ratio of protein concentration, expressed in $\mathrm{mg} / \mathrm{mL}$, in the top phase $\left(C_{T}\right)$ to that in the bottom phase $\left(C_{B}\right)$ :

$$
K_{p}=\frac{C_{T}}{C_{B}}
$$

Yield $(Y)$ was defined as the ratio of hemagglutinating activity in the bottom phase $\left(H A_{B}\right)$ to that in the crude extract $\left(H A_{I}\right)$, expressed in percentage as follows, $V_{B}$ and $V_{I}$ representing the volumes of bottom phase and crude extract, respectively.

$$
Y=\frac{H A_{B \times} V_{B}}{H A_{I \times} V_{I}} \times 100
$$

PF was calculated as the ratio of specific hemagglutinating activity in the bottom phase $\left(H A E_{B}\right)$ to the initial specific hemagglutinating activity in the crude extract $\left(H A E_{I}\right)$, as described in the equation:

$$
\mathrm{PF}=\frac{H A E_{B} / C_{B}}{H A E_{I} / C_{I}}
$$

where $C_{B}$ and $C_{I}$ represent the total protein concentrations in the bottom phase and crude extract, respectively and were expressed in $\mathrm{mg} / \mathrm{mL}$.

\section{Polyacrylamide gel electrophoresis}

sodium dodecyl sulfate- polyacrylamide gel electrophoresis (SDS-PAGE) was performed on a $10 \%(\mathrm{w} / \mathrm{v})$ gel according to Laemmli $^{[52]}$ and was stained with Coomassie Brilliant Blue R-250.

\section{Results and discussion}

The aim of this work is to report enhanced operational conditions for the use of $C$. mollis seeds in large scale aiming to therapeutic conditions. The evaluation of different techniques has been used, although none presented higher quantities compared to ATPS.

PEG-phosphate ATPS was evaluated as an alternative method to recovery and purify lectins (Cramoll 1,4) of the crude extract from C. mollis seeds. A full factorial design $2^{4}$ with PEG molar mass $\left(M M_{\mathrm{PEG}}\right)$ and concentration $\left(C_{\mathrm{PEG}}\right)$, salt concentration $\left(C_{\mathrm{P}}\right)$, and $\mathrm{pH}$ were the independent variables considered and a subsequent CCD to find the optimal levels of the selected most significant factors $\left(C_{\mathrm{PEG}}\right.$ and $\left.C_{\mathrm{P}}\right)$ were used. The response variables considered were the partition coefficient of protein and hemagglutinating activity $\left(K_{\mathrm{P}}\right.$ and $\left.K_{\mathrm{HA}}\right), \mathrm{PF}$, and the yield ( $\left.Y \%\right)$. 


\section{$2^{4}$ full factorial design}

Very limited information has been reported about the use of ATPS in lectins purification processes. Table 1 shows the results from 20 runs of the $2^{4}$ experimental design. In general, the total protein preferentially partitioned to the PEG rich phase (top) as confirmed by $K_{\mathrm{P}}$ values higher than 1 $\left(K_{\mathrm{P}}>1\right)$, with the exception of run 5 where there was not phase formation and run 7 with a $K_{\mathrm{P}}=0.7$. In contrast, in the most of run, partition coefficients of lectins were less than $1\left(K_{\mathrm{AH}}<1\right)$, suggesting that lectins partitioned to the bottom phase while proteins contaminant of the crude extract were top phase. It can be observed by increase of specific hemagglutinin activity of $1005 \mathrm{Ha} / \mathrm{mg}$ from crude extract to $4357 \mathrm{HA} / \mathrm{mg}$ from the bottom phase ATPS systems (run 9, Table 1). It suggests that the proteins found in the top phase and interphase were not lectins but most likely contaminants. The same effects were observed by Soares et al. ${ }^{[45]}$ using PEG/phosphate ATPS to extraction lectin from Canavalia ensiformis seeds.

On the other hand, in the runs 12 and 16 which have $17.5 \%(\mathrm{w} / \mathrm{w})$ PEG 8000 and $15 \% C_{\mathrm{P}}$, both $K_{\mathrm{HA}}$ and $K_{\mathrm{P}}$ obtained values higher than 1 (Table 1), showing that under these conditions, both lectin such as proteins contaminants of EC migrated to the top phase being not a system suitable for extraction/purification.

In most of the systems, the lectin yield $(Y)$ had values above $100 \%$. It has frequently been reported for protein extraction using liquid-liquid systems. Mayerhoff et al. ${ }^{[48]}$ explained this behavior by the elimination of inhibitor from the target biomolecule during extraction which may enhance the activity. The operation is likely occurs with the lectin carbohydrate site. ${ }^{[47]}$ Nascimento et al. ${ }^{[46]}$ obtained a $160 \%$ activity yield for lectins from the crude extract of C. mollis seeds, with a PEG/citrate system, while Porto et al. ${ }^{[44]}$ obtained a 525\% activity yield for hemagglutinin extraction from Canavalia (ConGF) with PEG/citrate, and Kelany et al. ${ }^{[45]}$ obtained a $116.8 \%$ activity yield for lectin extraction from Canavalia brasilienses seeds with PEG/phosphate.

Figures 1 and 2 shows the statistical analysis on variable responses $K_{\mathrm{P}}, K_{\mathrm{HA}}, \mathrm{PF}$ and $Y$ were performed through the Pareto chart. The figures represent the estimated effects of independent variables and their interactions on responses in decreasing order of magnitude, where the length of each bar is proportional to the standardized effect and the vertical dotted line on the right highlights statistically significant effects at $95 \%$ confidence level.

Experimental data and the graphical analysis on the effects of independent variables and their related interactions on $K_{\mathrm{P}}$ (Figure $1 \mathrm{~A}$ ) show that independent variables $C_{\mathrm{P}}$, $M M_{\mathrm{PEG}}$, and $\mathrm{pH}$ interaction have a positive and significative effect on $K_{\mathrm{p}}$, while $\mathrm{pH}$ has negative effects. This result indicates that increase in both independent variables $\left(C_{\mathrm{P}}\right.$ and $\left.M M_{\mathrm{PEG}}\right)$ increase the $K_{\mathrm{P}}$ and an increase in the $M M_{\mathrm{PEG}}$ with simultaneous decrease in the $\mathrm{pH}$ increase the $K_{\mathrm{P}}$. $C_{\mathrm{PEG}}$ was not significant to $K_{\mathrm{P}}$ values (Figure $1 \mathrm{~A}$ ), but it positively influenced the $K_{\mathrm{HA}}$, as well as $C_{\mathrm{P}}$ and $M M_{\mathrm{PEG}}$ (Figure 1B), shown to be important factors to lectin partition. $C_{\mathrm{PEG}}$ and $C_{\mathrm{P}}$ are important variables to separate the lectin from the
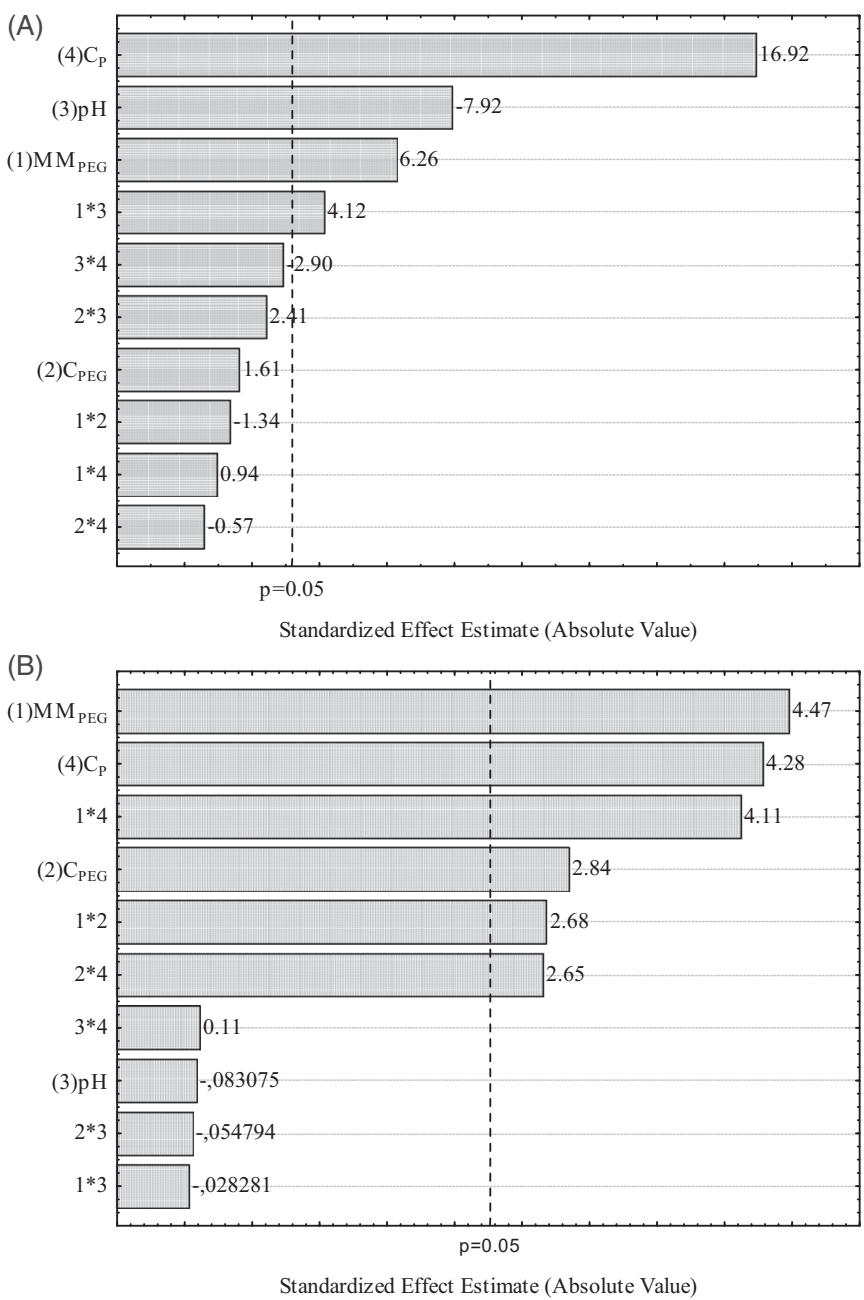

Figure 1. Pareto chart for the standardized effects of the variables: PEG molar mass $\left(M M_{\mathrm{PEG}}\right)$, PEG concentration $\left(C_{\mathrm{PEG}}\right)$, phosphate concentration $\left(C_{\mathrm{p}}\right)$, and $\mathrm{pH}$ on the (A) protein partition coefficient and (B) hemagglutinating activity partition coefficient of extraction.

protein contaminants in the EC of the C. molis. Similar effects were observed by Nascimento et al. ${ }^{[46]}$ showed that citrate concentration was a significant variable for $K_{\mathrm{HA}}$ using PEG/citrate systems for the extraction of lectins from a CE of C. mollis.

A similar analysis was carried out for the activity yield $(\mathrm{Y}$; Figure 2A) and purification factor (PF; Figure 2B) on bottom phase. The highest purification factor (5.02) was obtained at run 9 , with a corresponding $150 \%$ activity yield. The highest activity yield (230\%) was obtained at run 7, but with lower purification factor (3.84; Table 3). A purification factor of 13.5 but with a lower activity yield of $125 \%$ was reported for Cramoll 1,4 extracted directly from the EC of C. mollis using a PEG/phosphate ATPS. ${ }^{[4]}$ PEG/phosphate ATPS was used for the isolation of lectin from the CE of $C$. brasilienses obtained purification factor of 1.7 and yield of $116.8 \%$, being considered the most efficient for the purification of ConBr lectin. ${ }^{[46]}$ These values are much lower than those obtained in this work.

The independent variable $M M_{\mathrm{PEG}}$ was the only one with a significant negative effect, indicating that its decrease causes improved $Y$ and PF (Figure 2). Low $M M_{\mathrm{PEG}}$ decreases the hydrophobicity of the top phase inducing the 


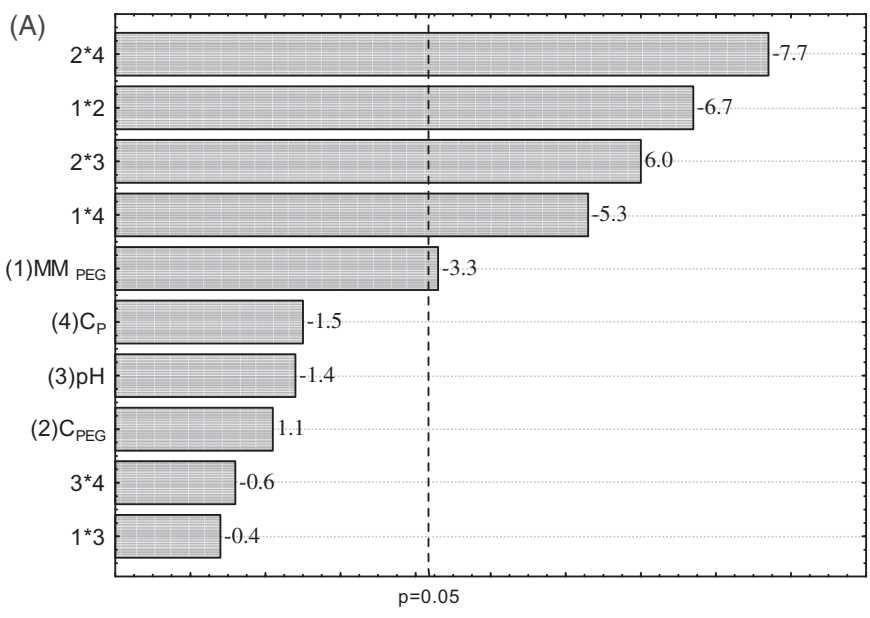

Standardized Effect Estimate (Absolute Value)

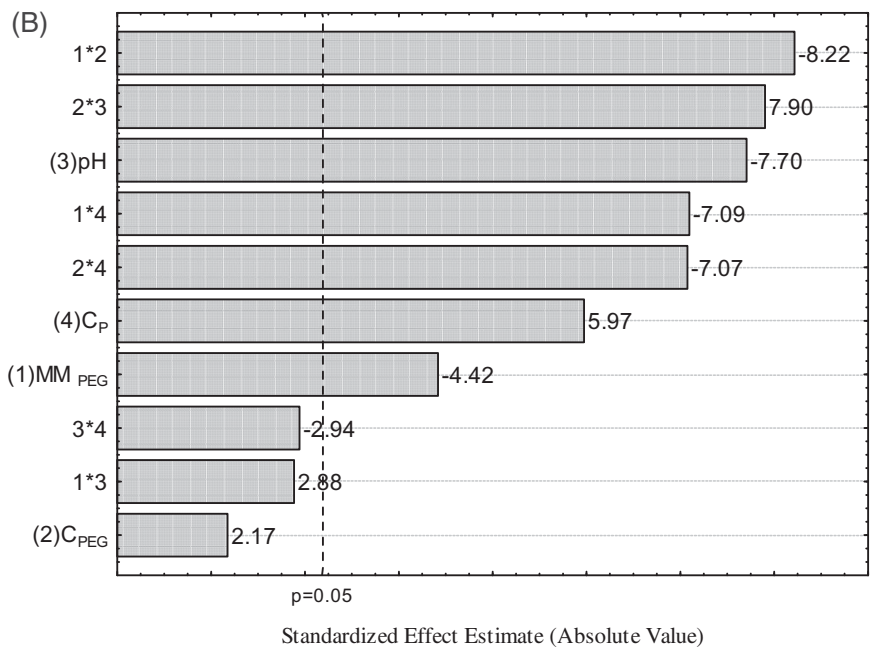

Figure 2. Pareto chart for the standardized effects of the variables: PEG molar mass $\left(M M_{\mathrm{PEG}}\right)$, PEG concentration $\left(C_{\mathrm{PEG}}\right)$, phosphate concentration $\left(C_{\mathrm{C}}\right)$, and $\mathrm{pH}$ on the $(A)$ hemagglutinating activity yield and $(B)$ purification factor of extraction in the bottom phase.

migration of the lectin to the bottom phase which increases $Y$ in this phase. So, the $M M_{\mathrm{PEG}}$ had negative significant effect on PF (Figure 2B). Proteins with more a polar amino acid residue show a higher affinity for the PEG phase, which is more hydrophobic than the bottom salt phase Yucekan and Onal, ${ }^{[53]}$ while those with more polar amino acid residues will likely demonstrate affinity for the salt phase.

Legume lectins such as ConBr and other ConA and Cramoll 1,4 are characterized by having hydrophobic sites and preferentially partitioned to PEG-rich phase. ${ }^{[40,44,45]}$ In the present work, lower $M M_{\mathrm{PEG}}$ decreased the hydrophobicity of the top phase and the lectin to migrate to the bottom phase. Similarly, ConA also partitioned to bottom phase using $\mathrm{PEG} /$ citrate $^{\text {systems }}{ }^{[45]}$ and lectins from the crude extract of C. mollis seeds using PEG/citrate systems. ${ }^{[46]}$

When analyzing Figure 2B, the negative effect of $\mathrm{pH}$ on $\mathrm{PF}$ can be observed. When $\mathrm{pH}$ decreases from 8 to 6 , the $\mathrm{PF}$ increased from 2.56 (run 13) to 5.02 (run 9). Nascimento et al. ${ }^{[43]}$ studied the purification of ConBr finding that the $\mathrm{pH}$ value was statistically important. In general, negatively charged proteins prefer the upper phase in PEG-salt systems,
Table 3. Conditions and results of lectin extraction to according the $2^{4}$ experimental design.

\begin{tabular}{lccccllll}
\hline Run & $M M_{\mathrm{PEG}}{ }^{\mathrm{a}}$ & $C_{\mathrm{PEG}}{ }^{\mathrm{b}}$ & $\mathrm{pH}$ & $C_{\mathrm{P}}{ }^{\mathrm{c}}$ & $K_{\mathrm{P}}{ }^{\mathrm{d}}$ & $K_{\mathrm{AH}}{ }^{\mathrm{e}}$ & $\mathrm{PF}^{\mathrm{f}}$ & $Y(\%)^{\mathrm{g}}$ \\
\hline 1 & 1500 & 12.5 & 6.0 & 10 & 1.08 & 0.031 & 2.36 & 120 \\
2 & 8000 & 12.5 & 6.0 & 10 & 1.41 & 0.031 & 2.7 & 125 \\
3 & 1500 & 17.5 & 6.0 & 10 & 1.38 & 0.015 & 3.06 & 110 \\
4 & 8000 & 17.5 & 6.0 & 10 & 1.4 & 0.125 & 3.03 & 140 \\
5 & 1500 & 12.5 & 8.0 & 10 & $-^{\mathrm{h}}$ & $-{ }^{\mathrm{h}}$ & $-^{\mathrm{h}}$ & $-^{\mathrm{h}}$ \\
6 & 8000 & 12.5 & 8.0 & 10 & 1.33 & 0.031 & 2.53 & 130 \\
7 & 1500 & 17.5 & 8.0 & 10 & 0.73 & 0 & 3.84 & 230 \\
8 & 8000 & 17.5 & 8.0 & 10 & 1.19 & 0.062 & 2.36 & 115 \\
9 & 1500 & 12.5 & 6.0 & 15 & 3.27 & 0 & 5.02 & 150 \\
10 & 8000 & 12.5 & 6.0 & 15 & 3.66 & 0.5 & 4.79 & 150 \\
11 & 1500 & 17.5 & 6.0 & 15 & 3.1 & 0.062 & 4.83 & 140 \\
12 & 8000 & 17.5 & 6.0 & 15 & 3.22 & 2 & 1.04 & 32.5 \\
13 & 1500 & 12.5 & 8.0 & 15 & 1.46 & 0.015 & 2.56 & 140 \\
14 & 8000 & 12.5 & 8.0 & 15 & 2.47 & 0.5 & 1.85 & 90 \\
15 & 1500 & 17.5 & 8.0 & 15 & 1.79 & 0.062 & 3.49 & 125 \\
16 & 8000 & 17.5 & 8.0 & 15 & 3.17 & 2 & 2.37 & 67.5 \\
$17^{\mathrm{i}}$ & 4000 & 15 & 7.0 & 12.5 & 2.15 & 0.062 & 3.55 & 150 \\
$18^{\mathrm{i}}$ & 4000 & 15 & 7.0 & 12.5 & 2.26 & 0.062 & 3.59 & 120 \\
$19^{\mathrm{i}}$ & 4000 & 15 & 7.0 & 12.5 & 1.8 & 0.062 & 3.07 & 130 \\
$20^{\mathrm{i}}$ & 4000 & 15 & 7.0 & 12.5 & 1.98 & 0.062 & 3.59 & 140 \\
\hline
\end{tabular}

a PEG molar mass $(\mathrm{g} / \mathrm{mol})$.

${ }^{\mathrm{b}}$ PEG concentration (\% w/w).

'Phosphate concentration (\% w/w).

${ }^{\mathrm{d}}$ Protein partition coefficient.

${ }^{\mathrm{e} A c t i v i t y ~ p a r t i t i o n ~ c o e f f i c i e n t . ~}$

fPurification factor in the bottom phase.

${ }^{9}$ Activity yield in the bottom phase.

${ }^{\text {h}}$ Phase formation did not occur.

'Central point repetitions.

while positively charged proteins normally partition to the bottom phase. ${ }^{[46]}$ Lectin from C. mollis has an isoelectric point about $\mathrm{pH} 8.5-8.6,{ }^{[4]}$ being thus positively charged at range $\mathrm{pH}$ between 6 and 8 , partitioning preferentially to the negatively charged lower phase (salt-rich phase). This effect was also observed in the extraction of Con A from crude extract of C. ensiformis seeds using PEG/Citrate ATPS. ${ }^{[45]}$

In addition, $C_{\mathrm{PEG}}$ and $C_{\mathrm{P}}$ influence the partitioning of $K_{\mathrm{HA}}$. A negative interaction effect between $C_{\mathrm{PEG}}$ and $C_{\mathrm{P}}$ was observed to $K_{\mathrm{HA}}, Y$, and $\mathrm{PF}$, indicating a synergism between the two variables. Thus, higher $K_{\mathrm{HA}}, Y$, and $\mathrm{PF}$ values will be obtained if increase $C_{\mathrm{P}}$ and decrease $C_{\mathrm{PEG}}$, simultaneously. The concentration of salt required to form the two phases depends on its salting out ability, and thus SC and PC require less concentration while AC requires more concentration. These preliminary results allowed the determination of the parameters that are relevant to the partitioning of lectin and allowed the development of the following $2^{2}$ experimental design (Table 2). It was used to investigate the experimental region close to the best condition from the first design. Briefly, polymer and salt concentration were the most important variables affecting partition of lectin were chosen for modeling and optimization in this work. $C_{\mathrm{PEG}}$ and $C_{\mathrm{P}}$ were the variables chosen for PF lectin optimization while that $\mathrm{pH} \quad 6$. and $1500 \mathrm{MM}_{\mathrm{PEG}} \quad(\mathrm{g} / \mathrm{mol})$ was fixed.

\section{Optimization of partitioning conditions using response surface methodology}

A positive and significant correlation $(r=0.961)$ was found between the PEG and salt concentrations applied to 
determine the best assay to purify the lectin. For the development of successful ATPS for recovery and purification of lectin, RSM was applied to determine the optimal levels of variables. The values of responses $\left(K_{\mathrm{P}}, K_{\mathrm{HA}}, \mathrm{PF}\right.$, and $\left.Y\right)$ at different experimental combination were given in Table 2. It can be seen from Table 1 that there was a considerable variation in the responses depending upon the $C_{\mathrm{PEG}}$ and $C_{\mathrm{P}}$ conditions. To employing multiple regression analysis on the experimental data, the predicted response for $K_{\mathrm{P}}, K_{\mathrm{HA}}$, and $Y$ were no regular relation between the partition parameters and phase concentrations, while that the PF can be obtained by the following second-order polynomial equation:

$$
\begin{aligned}
\mathrm{PF}= & -115+6.14 C_{\mathrm{PEG}}-0.10 C_{\mathrm{PEG}}{ }^{2}+10.0 C_{\mathrm{P}} \\
& -0.23 C_{\mathrm{P}}^{2}-0.21 C_{\mathrm{PEG}} . C_{\mathrm{P}}
\end{aligned}
$$

where $C_{\mathrm{PEG}}$ and $C_{\mathrm{P}}$ were the uncorded values of the test variables, PEG concentration and salt concentration, respectively.

The analytical variance and statistical significance of regression equation was checked by $F$-test, and the ANOVA for response surface quadratic polynomial model was done by software Design-Expert. The ANOVA of quadratic regression model demonstrated that the model was highly significant $(p \leq 0.05)$. The goodness of the model can be checked by the determination coefficients $\left(R^{2}=0.90\right)$, suggesting that the total variation of $90 \%$ for the PF of lectin was attributed to the independent variables and only about $10 \%$ of the total variation cannot be explained by the model. Closer the values of $\mathrm{R}$ to 1 , better the correlation between experimental and predicted values. ${ }^{[53]}$ All achieved data confirmed that the $C_{\mathrm{P}}$ and $C_{\mathrm{PEG}}$ factors were very critical for the partitioning and recovery of lection. Hence, these were the variables chosen to plot the response surfaces for the purification factor (Figure 3).

The three-dimensional response surface was the graphical representations of regression equation. They provide a method to visualize the relationship between responses and experimental levels of each variable and the type of interactions between two test variables. In addition, the optimum level of each variable for maximum response can be well understood. In the present study, two independent response surface plots were generated using design-expert as shown in Figure 3. The intermediate values of $C_{\mathrm{PEG}}$ and $C_{\mathrm{P}}$ favored the highest $\mathrm{PF}$. The plots exhibited a pronounced increase in $\mathrm{PF}$ when $C_{\mathrm{PEG}}$ and $C_{\mathrm{P}}$ were increased to intermediate values, and a slight decline as $C_{\mathrm{PEG}}$ and $C_{\mathrm{P}}$ was decreased.

\section{Experimental validation of model}

According to the optimized model, the highest value of PF for lectin was obtained in the region of $13.9 \%(w / w)$ PEG$1500,15.3 \%(\mathrm{w} / \mathrm{w})$ phosphate buffer at $\mathrm{pH} 6$. The predicted conditions were verified by conducting an experiment with model predicted values. As observed, PF of lectin obtained by optimized conditions was very close to model predicted value. Hence, it can be concluded that the predicted optimal condition from modeling was in good agreement with

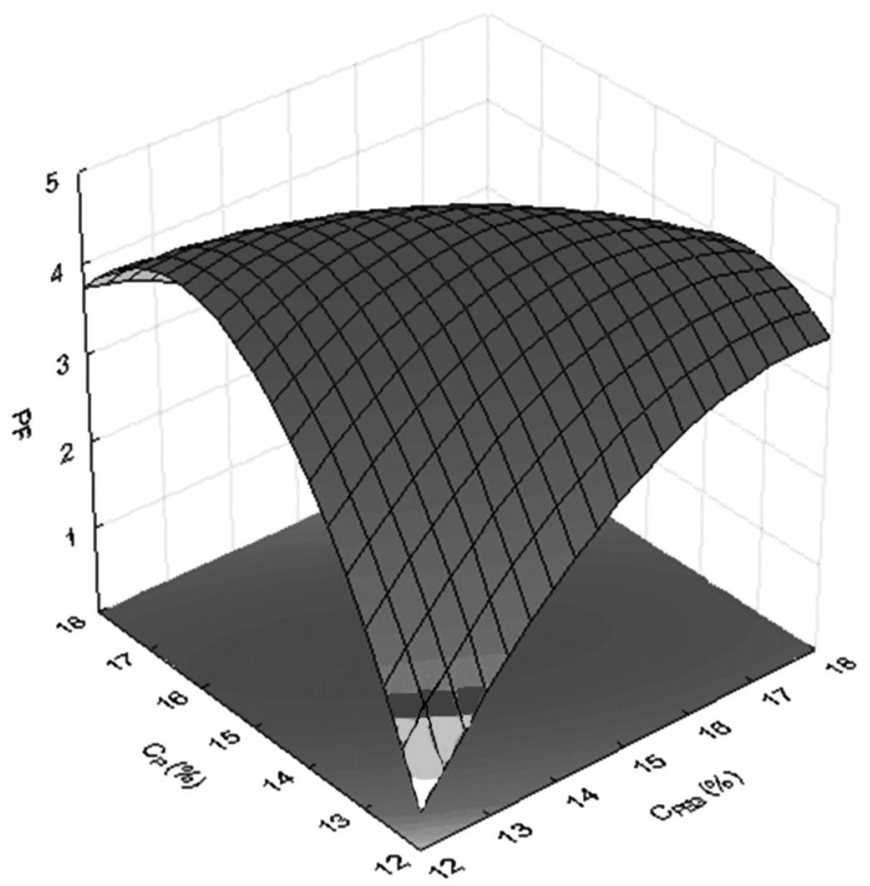

Figure 3. Response surface curve of purification factor of lectin as a function of PEG $\left(C_{\mathrm{PEG}}\right)$ and phosphate $\left(C_{\mathrm{P}}\right)$ concentration.

experimental results. To confirm that the optimum conditions can provide desired results, purity of the lectin were investigated as well by SDS-PAGE analysis (Figure 4). The highly purified lectin was found in the salt-rich phase and appeared as single bands on coomassie brilliant blue stained gel. The subunit MW of lectin was estimated to be about $26 \mathrm{kDa}$, which was like the reported values for Cramoll 1,4. ${ }^{[4,46]}$

\section{Partial characterization of lectins extracted by aqueous two-phase systems}

The results showed similar characteristics to those found by Correia and Coelho, ${ }^{[4]}$ purifying by chromatographic techniques. Figure 4 shows SDS-PAGE of crude extract from $C$. mollis seeds (A) and the lectin purified (Cramoll 1,4) after ATPS extraction (B) in the bottom phase of the system. The analysis of crude extract shows multiples bands (Lane 2) and the sample purified Cramoll 1,4 shows three bands (Lane 3 and 4) with a main band at $26 \mathrm{kDa}$. Also, the glycoprotein staining (PAS) after PAGE to evaluate their glycoprotein nature, confirmed that they are not glycoproteins. The temperature stability test showed that the hemagglutinating activity decreased from 512 to 128 at $60^{\circ} \mathrm{C}$ and reached zero at $80^{\circ} \mathrm{C}$. It was inhibited by glucose, mannose, and methyl- $\alpha$-D-mannosidase. Lectins also were submitted to PAS after PAGE to evaluate their glycoprotein nature, being confirmed that they are not glycoproteins. HA (512) was unaffected when lectins were heated at $40^{\circ} \mathrm{C}$ but decreased (128) at $60^{\circ} \mathrm{C}$ and was totally lost at $80^{\circ} \mathrm{C}$. Inhibition of purified Cramoll 1,4 HA occurred in the presence of glucose, mannose, and methyl- $\alpha$-D-mannoside. 


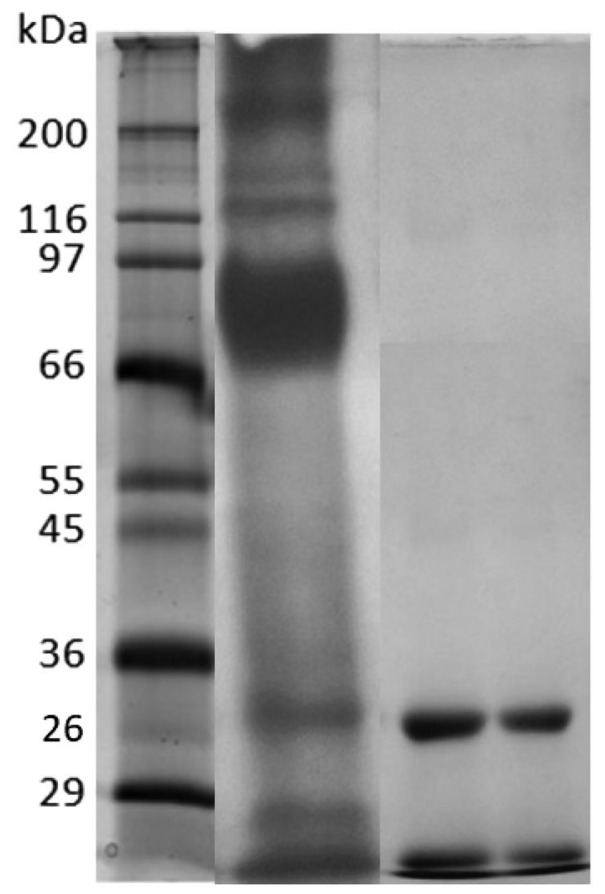

Figure 4. SDS-PAGE of the lectin purified. Lane 1: crude extract; Lane $S_{1:}$ the molecular weight of the standard protein marker ranged between $62-19 \mathrm{KDa}$; Lanes 2 and 3: purify lectin using ATPS, with 50 and $25 \mu \mathrm{g}$ of protein, respectively, and Lane $S_{2}$ : the molecular weight of the standard protein marker ranged between 200 and $19 \mathrm{KDa}$. Crude extract from (A) C. mollis seeds and (B) the lectin from C. mollis seeds after purified by PEG 1, 500/phosphate ATPS systems at $\mathrm{pH} 6.0$ in bottom phase.

\section{Conclusion}

There are several factors influencing the partitioning behavior of proteins in ATPS, especially when the protein of interest is contained in a complex mixture. The lectin partitioning behavior in PEG/phosphate ATPS can be controlled by an adequate selection of system properties. Critical parameters like PEG concentration and salt concentration were optimized using RSM method. After optimization, the best ATPS was 13.9\% (w/w) PEG 1500 and 15.3\% (w/w) phosphate buffer at pH 6 obtained PF to Cramoll 1,4 of 4.7. A good agreement was achieved between the experimental and predicted results, which verified the validity of proposed model. By using this system, the lectin partitioned to the bottom phase with purification being done in a single extraction step with similar results to those obtained by affinity chromatography. Additionally, ATPS purified lectins were homogenous on SDS-PAGE, presenting three bands with molecular weights of $26 \mathrm{kDa}$, as previously reported to Cramoll 1,4. Collectively, the feasibility of ATPS optimization using RSM approach for purification of lections was shown in this article. Due to the cost-effectiveness of the process, the PEG/phosphate ATPS may be considered as valuable alternative to purify lectins from crude extract of $C$. mollis seeds, with potential to be implemented as a commercial purification process.

\section{Funding}

We are grateful to the following bodies for the grants awarded: CAPES (Coordination for the Improvement of Level Personnel Superior);
FACEPE (Pernambuco Science and Technology Foundation): Researcher's scholarship grant: BFP-0017-5.05/18 CNPq (National Council for Scientific Development and Technological) process: 427153/2016-6 and we also thank the reviewers for their valuable comments and suggestions as these helped us to improve the manuscript.

\section{ORCID}

Tatiana Souza Porto (D) http://orcid.org/0000-0002-1571-8897 Maria Tereza dos Santos Correia (iD) http://orcid.org/0000-00034920-9975

Ana Lúcia Figueiredo Porto (D) http://orcid.org/0000-0001-5561-5158

\section{References}

[1] Sharon, N.; Lis, H. History of lectins: from hemagglutinins to biological recognition molecules. Glycobiology 2004, 14, 53-62.

[2] Sharon, N.; Gallagher, J. Glycobiology Marches on with a Subtle Blend of Tastes and Flavours. Curr. Opin. Struct. Biol. 2007, 17, 495-497.

[3] Paiva, P. M. G.; Coelho, L. C. B. B. Purification and Partial Characterization of Two Lectin Isoforms from Cratylia mollis mart (Camaratu Bean). Appl. Biochem. Biotechnol. 1992, 36, 113-118.

[4] Correia, M. T. S.; Coelho, L. C. B. B. Purification of glucose/ mannose lectin, isoform 1 from seeds of cratylia mollis Mart. feijão camaratu. Appl. Biochemi. Biotechnol. 1995, 55, 261-273.

[5] Silva, P. M. S.; Amanda, L. R. L.; Silva, B. V. M.; Coelho, L. C. B. B.; Dutra, R. F.; Correia, M. T. S. Cratylia mollis Lectin Nanoelectrode for Differential Diagnostic of Prostate Cancer and Benign Prostatic Hyperplasia Based on Label-Free Detection. Biosens. Bioelectron. 2016, 85, 171-177. DOI: 10. 1016/j.bios.2016.05.004.

[6] Maciel, E. V. M.; Araújo-Filho, V. S.; Nakazawa, M.; Gomes, Y. M.; Coelho, L. C. B. B.; Correia, M. T. S. Mitogenic Activity of Cratylia mollis Lectin on Human Lymphocytes. Biologicals 2004, 32, 57-60. DOI: 10.1016/j.biologicals.2003.12.001.

[7] Andrade, C. A. S.; Correia, M. T. S.; Coelho, L. C. B. B.; Nascimento, S. C.; Santos-Magalhães, N. S. Antitumor Activity of Cratylia mollis Lectin Encapsulated into Liposomes. Int. J. Pharm. 2004, 278, 435-445. DOI: 10.1016/j.ijpharm.2004.03. 028.

[8] Paiva, P. M. G.; Souza, A. F.; Oliva, M. L. V.; Kennedy, J. F.; Cavalcanti, M. S. M.; Coelho, L. C. B. B.; Sampaio, C. A. M. Isolation of a trypsin inhibitor from Echinodorus paniculatus seeds by affinity chromatography on immobilized Cratylia mollis isolectins. Bioresource Technol. 2003, 88, 75-79. DOI: 10. 1016/S0960-8524(02)00272-9.

[9] Lima, V. L. M.; Correia, M. T. S.; Cechinel, Y. G. M. N.; Sampaio, C. A. M.; Owenand, J. S.; Coelho, L. C. B. B.; Correia, T. S.; Cechinel, Y. G. M. N.; Sampaio, C. A. M.; Owenand, J. S.; et al. Immobilized Cratylia mollis Lectin as a Potential Matrix to Isolate Plasma Glycoproteins, Including Lecithin-Cholesterol Acyltransferase. Carbohydr. Polym. 1997, 33, 27-32. DOI: 10. 1016/S0144-8617(97)00034-9.

[10] Melo, C. M. L.; Castro, M. C. A. B.; Oliveira, A. P.; Gomes, F. O. S.; Pereira, V. R. A.; Correia, M. T. S.; Coelho, L. C. B. B.; Paiva, P. M. G. Immunomodulatory response of Cramoll 1,4 lectin on experimental lymphocytes. Phytother. Res. 2010, 24 1631-1636. DOI: $10.1002 /$ ptr.3156.

[11] Lima, A. L. R.; Cavalcanti, C. C. B.; Silva, M. C. C.; Paiva, P. M. G.; Coelho, L. C. B. B.; Beltrão, E. I. C.; Correia, M. T. S. Histochemical Evaluation of Human Prostatic Tissues with Cratylia mollis Seed Lectin. J. Biomed. Biotechnol. 2010, 1-7. DOI: 10.1155/2010/179817.

[12] Fernandes, M. P.; Inada, N. M.; Chiaratti, M. R.; Araújo, F. F. B.; Meirelles, F. V.; Correia, M. T. S.; Coelho, L. C. B. B.; Alves, M. J. M.; Gadelha, F. R.; Vercesi, A. E. Mechanism Of 
Trypanosoma cruzi Death Induced by Cratylia mollis Seed Lectin. J. Bioenerg. Biomembr. 2010, 42, 69-78. DOI: 10.1007/ s10863-010-9268-9.

[13] Melo, C. M. L.; Melo, H.; Correia, M. T. S.; Coelho, L. C. B. B.; Silva, M. B.; Pereira, V. R. A. Mitogenic response And Cytokine Production Induced by Cramoll 1,4 Lectin in Splenocytes of Inoculated Mice. Scand. J. Immunol. 2011, 73, 112-121. DOI: 10.1111/j.1365-3083.2010.02490.x.

[14] Silva, M. C. C.; Santana, L. A.; Silva-Lucca, R. A.; Lima, A. L. R.; Ferreira, J. G.; Paiva, P. M. G.; Coelho, L. C. B. B.; Oliva, M. L. V.; Zingali, R. B.; Correia, M. T. S. Immobilized Cratylia mollis Lectin: An Affinity Matrix to Purify aq Soybean (Glycine max) Seed Protein With In Vitro Platelet Antiaggregation and Anticoagulant Activities. Process Biochem. 2011, 46, 74-80. DOI: 10.1016/j.procbio.2010.07.017.

[15] Cunha, C. R. A.; Silva, L. C. N.; Almeida, F. J. F.; Ferraz, M. S.; Paz, N. V.; Cartaxo, M. F. S.; Miranda, R. C. M.; Aguiar, F. C. A.; Jr, Santos, N. P. S.; Coelho, L. C. B. B.; et al. Encapsulation into Stealth Liposomes Enhances the Antitumor Action of Recombinant Cratylia mollis Lectin Expressed in Escherichia coli. Front. Microbiol. 2016, 7.

[16] Silva, L. C. N.; Filho, C. M. B.; Paula, R. A.; Coelho, L. C. B. B.; Silva, M. V.; Correia, M. T. S. Cratylia mollis Lectin: A Versatile Tool for Biomedical Studies. Curr. Bioact. Comp. 2014, 10, 44-54.

[17] Oliveira, A. P. S.; Silva, L. L. S.; Lima, T. A.; Pontual, E. V.; Santos, N. D. L.; Coelho, L. C. B. B.; Navarro, D. M. A. F.; Zingalid, R. B.; Napoleão, T. H.; Paiva, P. M. G. Biotechnological value of Moringa oleifera seed cake as source of insecticidal lectin against Aedes aegypti. Process Biochem. 2016, 51, 1683-1690.

[18] Bensch, M.; Selbach, B.; Hubbuch, J. High Throughput Screening Techniques in Downstream Processing: Preparation, Characterization and Optimization of Aqueous Two-Phase Systems. Chem. Eng. Sci. 2007, 62, 2011-2021.

[19] Tanuja, S.; Srinivas, N. D.; Rao, K. S. M. S. R.; Gowthaman, M. K. Aqueous Two-Phase Extraction for Downstream Processing of Amyloglucosidase. Process Biochem. 1997, 32, 635-641. DOI: 10.1016/S0032-9592(97)00009-5.

[20] Nascimento, T. P.; Sales, A. E.; Porto, C. S.; Brandão, R. M. P.; Campos-Takaki, G. M.; Teixeira, J. A. C.; Porto, T. S.; Porto, A. L. F.; Converti, A. J. Purification of a Fibrinolytic Protease From Mucor Subtilissimus UCP 1262 by Aqueous Two-Phase Systems (PEG/Sulfate). Chromatogr. B.2016, 1025, 16-24. DOI: 10.1016/j.jchromb.2016.04.046.

[21] Rito-Palomares, M. Practical Application of Aqueous TwoPhase Partition to Process Development for the Recovery of Biological Products. J. Chromatogr. B Analyt. Technol. Biomed. Life Sci. 2004, 807, 3-11. DOI: 10.1016/j.jchromb.2004.01.008.

[22] Zaslavsky, B. Y. Aqueous Two Phase Partitioning - Physical Chemistry and Bioanalytical Applications; Marcel Dekker: New York, 1995.

[23] Hatti-Kaul, R. Aqueous Two-Phase Systems: Methods and Protocols. Humana Press, 2000; 11 pp.

[24] Fu, C.; Song, W.; Yi, C.; Xie, S. Creating Efficient Novel Aqueous Two-Phase Systems: Salting-Out Effect and High Solubility of Salt. Fluid Ph. Equilib. 2019, 490, 77-85. DOI: 10. 1016/j.fluid.2019.03.002.

[25] Shad, Z.; Mirhosseini, H.; Hussin, A. S. M.; Forghani, B.; Motshakeri, M.; Manap, M. Y. A. Aqueous Two-Phase Purification of $\alpha$-Amylase from White Pitaya (Hylocereus undatus) Peel in Polyethylene Glycol/Citrate System: Optimization by Response Surface Methodology. Biocatal. Agric. Biotechnol. 2018, 14, 305-313. DOI: 10.1016/j.bcab.2018.01.014.

[26] Albertsson, P. A. A Review of: Partition of Cell Particles and Macromolecules Wiley/Interscience, third edition, New York. Prep. Biochem. 1986, 16, 273-274.

[27] Sasakawa, S.; Walter, H. Partition Behavior of Native Proteins In Aqueous Dextran-Poly(Ethylene Glycol)-Phase Systems. Biochemistry 1972, 11, 2760-2765. DOI: 10.1021/bi00765a004.
[28] Johansson, G. Effects of salts on the partition of protein in aqueous polymeric two-phase systems. Acta Chem. Scand. B. 1974, 28, 873-884. DOI: 10.3891/acta.chem.scand.28b-0873.

[29] Asenjo, J. A.; Turner, R. E.; Mistry, S. L.; Kaul, A. Separation and Purification of Recombinant Proteins from Escherichia coli with Aqueous Two-Phase Systems. Chromatogr. A 1994, 668, 129-137. DOI: 10.1016/0021-9673(94)80101-0.

[30] Lin, D. Q.; Wu, Y. T.; Mei, L. H.; Zhu, Z. Q.; Yao, S. J. Modeling the Protein Partitioning in Aqueous Polymer TwoPhase Systems: Influence of Polymer Concentration and Molecular Weight. Chem. Eng. Sci. 2003, 58, 2963-2972. DOI: 10.1016/S0009-2509(03)00167-2.

[31] Nalinanon, S.; Benjakul, S.; Visessanguan, W.; Kishimura, H. Partitioning of Protease from Stomach of Albacore Tuna (Thunnus alalunga) by Aqueous Two-Phase Systems. Process. Biochem. 2009, 44, 471-476. DOI: 10.1016/j.procbio.2008.12. 018.

[32] Muendges, J.; Stark, I.; Mohammad, S.; Górak, A.; Zeiner, T. Single Stage Aqueous Two-Phase Extraction for Monoclonal Antibody Purification from Cell Supernatant. Fluid Ph. Equilib. 2015, 385, 227-236. DOI: 10.1016/j.fluid.2014.10.034.

[33] Kammoun, R.; Chouayekh, H.; Abid, H.; Naili, B.; Bejar, S. Purification of CBS $819.72 \alpha$-Amylase by Aqueous Two-Phase Systems: Modelling Using Response Surface Methodology. Biochem. Eng. J. 2009, 46, 306-312. DOI: 10.1016/j.bej.2009.06. 003.

[34] Silva, M. D. C.; Sá, R. S.; Napoleão, T. H.; Gomes, F. S.; Santos, N. D. L.; Albuquerque, A. C.; Xavier, H. S.; Paiva, P. M. G.; Correia, M. T. S.; Coelho, L. C. B. B. Purified Cladonia Verticillaris Lichen Lectin: Insecticidal Activity on Nasutitermes corniger (Isoptera: Termitidae). Int. Biodeter. Biodegr. 2009, 63, 334-340. DOI: 10.1016/j.ibiod.2008.11.002.

[35] Ooi, C. W.; Ti, B. T.; Ling, S. H.; Kamal, S. M. M.; Wei, L. C. J.; Arbakariya, A.; Tau, C. L. Purification of Lipase Derived from Burkholderia pseudomallei with Alcohol/SaltBased Aqueous Two-Phase Systems. Process. Biochem. 2009, 44, 1083-1087. DOI: 10.1016/j.procbio.2009.05.008.

[36] Bassani, G.; Fucinos, P.; Picó, G.; Farruggia, B. Candida rugosa Lipase Lip1-Polyethyleneglycol Interaction and the Relation with its Partition in Aqueous Two-Phase Systems. Colloid. Surface. B. 2010, 75, 532-537. DOI: 10.1016/j.colsurfb.2009.09. 031.

[37] Luechau, F.; Ling, T. C.; Lyddiatt, A. Primary Capture of High Molecular Weight Nucleic Acids Using Aqueous Two-Phase Systems. Sep. Purif. Technol. 2009, 66, 202-207. DOI: 10.1016/j. seppur.2008.12.008.

[38] Dembczynski, R.; Białas, W.; Regulski, K.; Jankowski, T. Lysozyme extraction from hen egg white in an aqueous twophase system composed of ethylene oxide-propylene oxide thermoseparating copolymer and potassium phosphate. Process. Biochem. 2010, 45, 369-374. DOI: 10.1016/j.procbio.2009.10. 011 .

[39] Porto, T. S.; Marques, P. P.; Porto, C. S.; Moreira, K. A.; LimaFilho, J. L.; Converti, A.; Pessoa, A.; Jr.; Porto, A. L. F. Extraction of Ascorbate Oxidase from Cucurbita maxima by Continuous Process in Perforated Rotating Disc Contactor Using Aqueous Two-Phase Systems. Appl. Biochem. Biotechnol. 2010, 160, 1057-1064. DOI: 10.1007/s12010-009-8631-y.

[40] Khayati, G.; Masumeh, A.; Shahidi, N. Partitioning of $\beta$-Galactosidase in Aqueous Two-Phase Systems Containing Polyethyleneglycol and Phosphate Salts. Fluid Ph. Equilib. 2015, 385, 147-152. DOI: 10.1016/j.fluid.2014.11.003.

[41] Silva, J. d C.; de França, P. R. L.; Porto, T. S. Optimized Extraction of Polygalacturonase from Aspergillus aculeatus URM4953 by Aqueous Two-Phase Systems PEG/Citrate. J. Mol. Liquids. 2018, 263, 81-88. DOI: 10.1016/j.molliq.2018.04.112.

[42] Zhang, C.; Medina-Bolivar, F.; Buswell, S.; Cramer, C. L. Purification and Stabilization of ricin B from Tobacco Hairy Root Culture Medium by Aqueous Two-Phase Extraction. J. Biotechnol. 2005, 117, 39-48. DOI: 10.1016/j.jbiotec.2004.12.015. 
[43] Kelany, S.; Nascimento, K. S.; Rosa, P. A. J.; Nascimento, K. S.; Cavada, B. S.; Azevedo, A. M.; Aires-Barros, M. R. An overview of lectins purification strategies. Sep. Purif. Technol. 2010, 75, 48-54. DOI: 10.1016/j.seppur.2010.07.008.

[44] Porto, C. S.; Porto, T. S.; Nascimento, K. S.; Teixeira, E. H.; Cavada, B. S.; Lima-Filho, J. L.; Porto, A. L. F. Partition of Lectin from Canavalia grandiflora Benth in Aqueous TwoPhase Systems Using Factorial Design. Bioch. Eng. J. 2011, 53, 165-171. DOI: 10.1016/j.bej.2010.10.006.

[45] Soares, P. A. G.; Nascimento, C. O.; Porto, T. S.; Correia, M. T. S.; Porto, A. L. F.; Carneiro-da-Cunha, M. G. Purification of a Lectin from Canavalia ensiformis Using PEG-Citrate Aqueous Two-Phase System. J. Chromatogr. B. 2011, 879, 457-460. DOI: 10.1016/j.jchromb.2010.12.030.

[46] Nascimento, C. O.; Soares, P. A. G.; Porto, T. S.; Costa, R. M. P. B.; Lima, C. d A.; de Lima Filho, J. L.; Coelho, L. C. B. B.; dos Santos Correia, M. T.; Carneiro da Cunha, M. d G.; et al. Aqueous Two-Phase Systems: new Strategies for Separation and Purification of Lctin from Crude Extract of Cratylia mollis Seeds. Sep. Purif. Technol. 2013, 116, 154-161. DOI: 10.1016/j. seppur.2013.05.012.

[47] Mayerhoff, Z. D. V. L.; Roberto, L. C.; Franco, T. T. Purification of Xylose Reductase from Candida mogii in Aqueous Two-Phase Systems. Biochem. Eng. J. 2004, 18, 217-223. DOI: 10.1016/j.bej.2003.09.003.
[48] Balasubramaniam, D.; Wilkinson, C.; Cott, K. V.; Zhang, C. Tobacco Protein Separation by Aqueous Two-Phase Extraction. J. Chromatogr. A. 2003, 989, 119-129. DOI: 10.1016/s00219673(02)01900-3.

[49] Smith, P. K.; Krohn, R. I.; Hermanson, G. T.; Mallia, A. K.; Gartner, F. H.; Provenzano, M. D.; Fujimoto, E. K.; Goeke, N. M.; Olson, B. J.; Klenk, D. C. Measurement of Protein Using Bicinchoninic Acid. Anal. Biochem. 1985, 150, 76-85. DOI: 10. 1016/0003-2697(85)90442-7.

[50] Rahimpour, F.; Pirdashti, M. Liquid-Liquid Equilibrium Data, Viscosities, Densities, Conductivities, and Refractive Indexes of Poly (vinyl pyrrolidone) + tri-sodium Citrate + Urea Aqueous Two-Phase Systems at Different pH. Int. J. Chem. Biomol. Eng. 2007, 5, 42-47.

[51] Azevedo, A. M.; Gomes, P. A. G.; Rosa, A. J.; Ferreira, I. F.; Pisco, A. M. M. O.; Aires-Barros, M. R. Partitioning of Human Antibodies in Polyethylene Glycol-Sodium Citrate Aqueous Two-Phase Systems. Sep. Purif. Technol. 2009, 65, 14-21. DOI: 10.1016/j.seppur.2007.12.010.

[52] Laemmli, U. K. Cleavage of Structural Proteins during the Assembly of the Head of Bacteriophage T4. Nature. 1970, 227, 680-685. DOI: 10.1038/227680a0.

[53] Yucekan, I.; Onal, S. Partitioning of invertase from tomato in poly(ethylene glycol)/sodium sulfate aqueous two-phase systems. Process. Biochem. 2011, 46, 226-232. 